COMMUNISM IN SOUTHEAST ASIA 
Macmillan International College Editions (MICE) are authoritative paperback books covering the history and cultures of the developing world, and its scientific, technical, social and economic development. The MICE programme contains many distinguished series in a wide range of disciplines, some titles being regionally biased, others more international. Library editions will usually be published simultaneously with the paperback editions.

\section{Titles of Related Interest}

China in Focus

H. Baker Chinese Family and Kinship

S. Aziz Rural Development - Learning from China

J. Gardner Chinese Politics and the Succession Problem

G. White \& P. Nolan Equality and Development in the People's Republic of China

M. Yahuda The End of Isolation: China's Foreign Policy after Mao

Macmillan Asian Histories Series

D. G. E. Hall A History of South-east Asia

R. Jeffrey (ed) Asia: the winning of independence

M. Ricklefs A History of Modern Indonesia

B. W. \& L. Y. Andaya A History of Modern Malaysia

Wang Gungwu China, the Chinese and S.E. Asia (3 volumes)

H. Goulbourne Politics and State in the Third World 


\title{
Communism in South-east Asia
}

\author{
Justus M. van der Kroef
}

General Editor: $\operatorname{Dr} A$. Short, University of Aberdeen

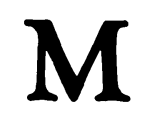


(C) Justus M. van der Kroef, 1981

Softcover reprint of the hardcover 1st edition 1981 978-0-333-24812-6

All rights reserved. No part of this publication may be reproduced or transmitted, in any form or by any means, without permission

First published 1981 by

THE MACMILLAN PRESS LTD

London and Basingstoke

Associated companies in Delhi Dublin

Hong Kong Johannesburg Lagos Melbourne

\section{British Library Cataloguing in Publication Data}

Van der Kroef, Justus M

Communism in South-east Asia.

1. Communism - Asia, Southeastern - History 2. Communist parties Asia, Southeastern History 3. Political parties - Asia, Southeastern History

I. Title

$329^{\prime} .02^{\prime} 0959$

HX751.A3

ISBN 978-0-333-24813-3 ISBN 978-1-349-16462-2 (eBook)

DOI 10.1007/978-1-349-16462-2

This book is sold subject to the standard conditions of the Net Book Agreement

The paperback edition of this book is sold subject to the condition that it shall not, by way of trade or otherwise, be lent, re-sold, hired out, or otherwise circulated without the publisher's prior consent in any form of binding other than that in which it is published and without a similar condition including this condition being imposed on the subsequent purchaser. 


\section{Contents}

Preface vii

1: Communism's rise in South-east Asia 1

A. Historical origins 1

B. The Communist victory in Indochina 36

C. A summing up: some characteristics of the 58

Communist evolution

2: The contemporary political environment 70
A. The non-Communist countries
70
B. Indochina 113
C. Summary: South-east Asian political patterns today 126

3: Party programmes and tactics

A. Class, race, and religion 133

B. The special case of the students 155

C. Vietnam and Laos 163

D. Cambodia $\quad 170$ 
4: Party organisation and appeals

A. The organisational outreach

B. The problem of armed insurrection

C. Three models for the search for power

D. Indochina

5: Between Peking and Moscow

A. Relations with People's China 218

B. ASEAN and Indochina 235

C. The influence of the USSR 242

D. The Indochina question and the world 251

6: Conclusion: a look ahead 261

A bibliographical note: suggestions for further reading

Notes

Index 


\section{Preface}

Compared to South-east Asia's other political and economic problems and developments, the rise, débâcles, resurgences, programmes and tactics of Communism and Communist parties in the region have suffered from a relative neglect. To be sure, the continuing conflict in Indochina first between the Communists and their opponents and now among Communist regimes themselves, has produced a spate of studies. But often these have focused only to a degree on the character of the Vietnamese Communist movement itself and more, say, on the balance between the two Vietnams or on the international implications of the US and allied involvement in the struggle in the region. Indonesian Communism similarly has been the subject of a number of studies in recent years. But the abortive 1965 coup in that country and the collapse of the Indonesian Communist Party have now tended to shift attention primarily to the Suharto regime's internal political and economic troubles or to its place in South-east Asia's post-Vietnam war regional security strategy. The Malayan jungle war between 1948 and 1960 during the so-called 'Emergency' has found its chroniclers but in Malaysian Communist developments since then scholarly interest has tended to wane. There are no full length or comprehensive up-to-date studies, certainly not in any Western languages, on the historical evolution and present state of Communism in Burma, Thailand or the Philippines. Yet all those are countries confronted by active Communist insurgent movements and active underground parties. Only an occasional essay in the past decade has focused on the more recent tribulations and tactics of Communist Parties in Peninsular Malaya and Sarawak. Particularly noteworthy is the dearth of comparative analytical approaches to South-east Asian Communism, e.g. of common themes in appeals to local classes and interest groups or in the use of common united front tactics. The last comprehensive volume which sought to describe the 
Communist movement in the region as a whole, the trailblazing study of Brimmell, is now twenty years old.*

Communism in South-east Asia in this writer's impression tends to be a lot talked about, but notwithstanding the furore surrounding the Vietnam war and its once much discussed possible 'domino' effects on neighbouring states, and despite such dramatic events as the failed 1965 coup in Indonesia, or an occasional daring raid by Thai or west Malaysian Communists, it has actually tended to be only little analysed. Most frequently it is considered to be a part of a larger public policy problem of finding a viable domestic political format in a given South-east Asian nation. Or again it is seen as an extraneous oddity, some unassimilated feature of the national body politic the exact implications of which are only dealt with in passing. To study Communism in South-east Asia per se as if it had, just possibly, distinctive dynamics or objectives of its own, might even be considered suspect, though the central political reality of South-east Asia as a region today is that one segment of it is in fact Communist (if internally quarrelling) and the other part pursues relentlessly antiCommunist domestic policies. The reason for the suspicion, the present writer conjectures, may not be unrelated to certain attitudes in some academic and other intellectual circles in the West which regard preoccupation with Communism, even in a scholarly sense, as somehow reflecting an ideological bias on the part of the researcher. In short, the ghosts of the McCarthy era and of the Cold War even now tend to make the primary study of Communism somehow less respectable and attractive as a field also to younger scholars, notwithstanding its obvious importance.

The following pages are in no way intended to fill the relative lacunae in Communist studies on South-east Asia. This book is intended primarily as an introductory survey for the general reader, although it is hoped that here and there the specialist may also find matters of interest. Along with offering an historical introduction to party origins and developments in earlier decades of this century, the book also attempts to relate Communist tactics and appeals in individual South-east Asian countries to problems of the national political and economic environments in which they must operate. Some attempt is made to trace the paradoxes arising out of official domestic anti-Communist policies in the non-Communist segment of

- J. H. Brimmell, Communism in South-east Asia: A Political Analysis (London: Oxford University Press, 1959). 
South-east Asia with the current attempts to reach a new modus vivendi with the Communist states of Indochina. Two chapters seek to approach, in a comparative way, the programmatic themes, social appeals and organisational structures of the Communist parties themselves. Communists in China even before the formation of the People's Republic there, as well as of course the USSR, historically have influenced South-east Asia's Communism, and in recent years, particularly since the end of the Vietnam war, both Moscow and Peking appear to have altered their perceptions of the policies pursued by governments in the region. A separate chapter seeks to analyse this Soviet-Chinese-South-east Asian interplay, also in light of the current conflict between $\mathrm{Hanoi}$ and its Cambodian opponents. Throughout these pages an effort is made to deal with Communist and non-Communist South-east Asia as separate entities, which are now compelled by circumstance to find means of responding to each other's needs and interests.

Many have assisted me with comments and advice during the preparation of this book. But I would especially wish to express my appreciation to the library staff of the University of Bridgeport for its ever friendly readiness to obtain needed reference materials. I am also particularly grateful to Mrs Judith Augusta for a conscientious and careful typing of a difficult manuscript.

This book is for J.O., isteri setiawan. 